\title{
IMPLEMENTASI HUKUM KHIYĀR DAN UNDANG-UNDANG NOMOR 8 TAHUN 1999 PADA PRAKTIK JUAL BELI ONLINE PADA ULIN OL SHOP PURWOREJO
}

\author{
Muhajir; Sekolah Tinggi Agama Islam An-Nawawi Purworejo, Jl. Ir. H. Juanda No. 1 Berjan \\ Gebang Purworejo 54191,E-mail: muhajirmadruslam@gmail.com
}

\begin{abstract}
Abstrak
Kajian ini membahas perlindungan terhadap hak-hak konsumen jual beli online melalui media sosial perspektif hukum Islam dan Pasal 7 UU No 8 Tahun 1999 tentang Perlindungan Konsumen. Melihat perkembangan usaha jual beli sekarang, pembahasan konsep perlindungan konsumen dalam jual beli online sangatlah penting, karena penulisan secara khusus yang berkaitan dengan hal ini masih kurang. Sekarang banyak pelaku usaha yang hanya mementingkan keuntungan pribadinya dan mengabaikan hak-hak konsumen, apalagi konsumen jual beli online yang transaksinya tidak bertemu secara langsung dan hanya melalui media social, salah satunya yang terpraktekkan oleh Ulin Ol Shop. Penelitian ini bertujuan mengetahui konsep perlindungan konsumen terhadap hak-hak konsumen jual beli online yang ada dalam Pasal 7 UU Perlindungan Konsumen dan perspektif hukum Islam. Hasil penelitian ini adalah, pertama bahwa pemberian potongan harga oleh Ulin Ol Shop merupakan salah satu bentuk tanggung jawab pelaku usaha berdasarkan Undang-Undang Perlindungan Konsumen. Kedua, Ulin Ol Shop telah melanggar Undang-Undang Perlindungan Konsumen dengan tidak memberikan informasi yang jelas terhadap produk yang diposting di media sosial. Ketiga, Ulin Ol Shop tidak menerapkan teori khiyār seperti yang telah diatur hukum Islam.
\end{abstract}

Kata Kunci: Perlindungan Konsumen, Jual Beli Online, Khiyār

\begin{abstract}
This research discusses the protection of the rights of online buying and selling consumers through social media from the perspective of Islamic law and Article 7 of Law No. 8 of 1999 concerning Consumer Protection. Seeing the development of buying and selling businesses now, the discussion of the concept of consumer protection in online buying and selling is essential, because specific writing related to this is still lacking. Many business actors are only concerned with their profits and ignore consumer rights, especially in online buying and selling consumers whose transactions do not meet in person and only through social media, one of which is practiced by Ulin Ol Shop. This study aims to determine the concept of consumer protection against the rights of online buying and selling consumers in Article 7 of the Consumer Protection Law and the perspective of Islamic law. The results of this study are, first, that the giving of discount prices by Ulin Ol Shop is a form of responsibility of business actors based on the Consumer Protection Act. Second, Ulin Ol Shop has violated the Consumer Protection Act by not providing clear information on products posted on social media. Third, Ulin Ol Shop does not apply the khiyār theory as regulated by Islamic law.
\end{abstract}

Keywords: Consumer Protection, Buying and Selling Online, Khiyār

\section{PENDAHULUAN}

\section{Latar Belakang}

Pada Pasal 7 UU Nomor 8 Tahun 1999 tentang Perlindungan Konsumen telah mengatur kewajiban pelaku usaha untuk menjaga hak-hak konsumen dalam transaksi jual beli. Pada pasal 7 poin E berbunyi "Memberi kesempatan pada konsumen untuk meng uji, dan/atau mencoba barang dan/atau jasa tertentu serta memberi jaminan dan/atau garansi atas barang yang dibuat dan/atau diperdagangkan". ${ }^{1}$ Hukum Islam juga mengatur mengenai perlindungan (hak-hak) konsumen, pelaku transaksi jual beli memiliki hak memilih

\footnotetext{
${ }^{1}$ Undang-Undang Republik Indonesia Nomor 8 Tahun 1999 tentang Perlindungan Konsumen.
} 
barang yang akan dibelinya untuk melanjutkan atau membatalkan akad jual beli, dengan demikian pada setiap transaksi jual beli pembeli dapat menentukan hak pilih yang dalam Islam dikenal dengan istilah khiyār. ${ }^{2}$

Salah satu pelaku usaha online di Purworejo adalah Ulin Ol Shop, di mana Ulin Ol Shop ini menyediakan berbagai macam barang-barang seperti kosmetik, baju, barangbarang perabotan rumah tangga dan makanan yang dipromosikan melalui berbagai macam media sosial, yaitu facebook, whatsApp dan Instagram. Promosi biasa dilakukan dengan memasang foto-foto barang dagangan di media sosial dan bagi konsumen yang berminat dapat secara langsung menghubungi Ulin Ol Shop melalui contact person yang telah disertakan dalam postingan barang yang dipromosikan.

Dalam menjalankan usahanya Ulin Ol Shop terkadang mendapat komplain dari konsumen. Ketika terjadi komplain barang biasanya Ulin Ol Shop memberikan potongan harga saja dan barang yang telah dibeli tidak bisa dikembalikan meskipun pembeli tidak menyukainya. Dalam Hukum Islam adanya khiyār adalah hak bagi pihak yang melakukan transaksi jual beli untuk memilih antara meneruskan atau membatalkan transaksi, namun pada kejadian pengaduan komplain di Ulin OlShop barang yang sudah dibeli tidak dapat dikembalikan meskipun konsumen kecewa. Sebagai ganti rugi Ulin Ol Shop hanya memberikan potongan harga.

\section{Rumusan Masalah}

Mempertimbangkan latar belakang di atas, rumusan masalah yang menjadi focus dalam penelitia ini adalah:

1). Bagaimana pelaksanaan Pasal 7 UU Nomor 8 Tahun 1999 tentang Perlindungan Konsumen pada praktik jual beli online di Ulin Ol Shop Purworejo?

2). Bagaimana pandangan Hukum Islam tentang praktik jual beli di Ulin Ol Shop Purworejo?

\section{METODE PENELITIAN}

Metode penelitian merupakan cara yang digunakan oleh penulis dalam mengumpulkan data penelitiannya. ${ }^{3}$ Penelitian ini merupakan penelitian hokum empiris, dimana penulis mengumpulkan data penelitian dengan cara meneliti secara langsung praktik jual beli online Ulin Ol Shop Purworejo. Metode analisis data menggunakan metode kualitatif yaitu metode analisis deduktif, dengan demikian hasil penelitiannya yakni menguji teori yang ada bagi suatu situasi secara konkrit, yaitu memadukan Pasal 7 Undang-Undang Nomor 8 tentang Perlindungan Konsumen dan Hukum Islam dengan implementasi nyata yang terjadi dalam kehidupan sekarang.

\footnotetext{
2 Yulia Hafizah. (2012).“Khiyar Sebagai Upaya Mewujudkan Keadilan dalam Bisnis Islami,” AtTaradhi Jurnal Studi Ekonomi 3, No. 02, h. 165-72.

${ }^{3}$ Suharsimi Arikunto. (2006). Prosedur Penelitian Suatu Pendekatan Praktek. Bandung: Rineka Cipta.
} 


\section{PEMBAHASAN}

\section{A. Landasan Teori}

Dalam Pasal 7 No 8 Tahun 1999 tentang Perlindungan Konsumen membahas tentang kewajiban pelaku usaha, yang isinya sebagai berikut: ${ }^{4}$

a. Beriktikad baik dalam melakukan kegiatan usahanya;

b. Memberikan informasi yang benar, jelas, dan jujur mengenai kondisi dan jaminan barang dan/atau jasa serta memberi penjelasan penggunaan, perbaikan, dan pemeliharaan;

c. Memperlakukan atau melayani konsumen secara benar dan jujur serta tidak diskriminatif;

d. Menjamin mutu barang dan/atau jasa yang diproduksi dan/atau diperdagangkan berdasarkan ketentuan standar mutu barang/atau jasa yang berlaku;

e. Memberi kesempatan kepada konsumen untuk menguji, dan/atau mencoba barang dan/atau jasa tertentu serta memberi jaminan dan/atau garansi atas barang yang dibuat dan/atau yang diperdagangkan;

f. Memberi kompensasi, ganti rugi dan/atau penggantian atas kerugian akibat penggunaan, pemakaian, dan pemanfaatan barang dan/atau jasa yang diperdagangkan;

g. Memberi kompensasi, ganti rugi dan/atau pengganti apabila barang dan/atau jasa yang diterima atau dimanfaatkan tidak sesuai dengan perjanjian.

Dengan demikian, pokok-pokok kewajiban produsen/pelaku usaha adalah beriktikad baik dalam menjalankan usahanya, memberikan informasi, memperlakukan konsumen dengan cara yang sama, menjamin produk-produknya, memberikan kesempata bagi konsumen untuk menguji, memberi kompensasi. Sebagai kewajiban hukum, maka pelaku usaha harus memenuhi dengan iktikad baik dan penuh tanggung jawab. Jika pelaku usaha bersalah karena tidak memenuhi kewajibannya itu menjadi alasan bagi pelaku usaha untuk dituntut secara hukum untuk mengganti kerugian yang timbul sehubung dengan tidak terpenuhinya kewajiban pelaku usaha. ${ }^{5}$

Kewajiban pelaku usaha yang lain adalah tentang menyampaikan informasi yang benar dan jelas mengenai suatu produk yang diperjual belikan, karena informasi merupakan hak konsumen dan jika informasi suatu produk tidak ada, maka hal ini menjadi salah satu penyebab cacat produk yang merugikan konsumen. Penyampaian informasi dapat berupa representasi, ${ }^{6}$ peringatan, maupun yang berupa instruksi. ${ }^{7}$

Kewajiban pelaku usaha pada dasarnya adalah untuk mencegah timbulnya kerugian yang akan dialami oleh konsumen, informasi yang benar dan jelas merupakan kewajiban

\footnotetext{
4 Undang-Undang Republik Indonesia Nomor 8 Tahun 1999 tentang Perlindungan Konsumen.

5 Aulia Muthiah. (2016). "Tanggung Jawab Pelaku Usaha kepada Konsumen tentang Keamanan Pangan dalam Perspektif Hukum Perlindungan Konsumen." Dialogia Iuridica: Jurnal Hukum Bisnis dan Investasi 7, No. 2, h. 1-23.

6 (KBBI) Perbuatan mewakili, merupakan gambaran berupa penjelasan suatu produk yang dituangkan ke dalam iklan.

7 Aulia Muthiah, Hukum Perlindungan Konsumen Dimensi Hukum Positif dan Ekonomi Syariah, h. 71.
} 
pelaku usaha demi kesempurnaan suatu produk, sebaliknya sebagai konsumen harus cermat dalam menerima informasi suatu produk dari pelaku usaha.

Pada dasarnya setiap akad yang sah menimbulkan ikatan antara para pihak, setiap ikatan ini menimbulkan kewajiban dan hak dari masing-masing pihak. Setiap akad yang dilakukan, dipersyaratkan adanya kerelaan (ridha) dari para pihak yang melakukan transaksi akad, maka syariat Islam menetapkan hak khiyār yang fungsi uta ma nya untuk menjamin syarat kerelaan itu terpenuhi. ${ }^{8}$

Khiyār dalam bahasa Arab berarti pilihan, secara istilah menurut ahli fikih, khiyār adalah hak yang dimiliki salah satu atau seluruh pihak akad untuk melanjutkan akad atau membatalkannya, baik karena alasan syar'i atau karena kesepakatan pihak-pihak akad. ${ }^{9}$ Dasar disyariatkannya khiyār adalah hadits yang diriwayatkan dari Ibnu Umar r.a, bahwa Rasulullah SAW bersabda:

“Dari Ibnu Umar ra, dari Rasulullah SAW bahwa beliau bersabda: Apabila dua orang melakukan jual beli, maka keduanya memiliki hak khiyar yang selama belum berpisah, dan keduanya masih berada di tempat jual beli; atau salah salah satunya memberikan khiyār (pilihan) yang lain, kemudian keduanya berjual beli dengan pilihan mereka berdua, jika demikian maka jual belinya sudah wajib (berlaku); Apabila keduanya berpisah setelah jual beli, walaupun belum meninggalkan tempat jual beli itu, maka jual belinya sudah berlaku." (HR. Bukhari) ${ }^{10}$

Khiyār terbagi berdasarkan dua hal, yaitu:

1. Kesepakatan para pihak (khiyār 'iradiyah)

a. Khiyār syarat

Khiyār syaraț adalah hak yang dimiliki salah satu atau seluruh pihak akad atau bagi orang lain untuk melanjutkan akad atau mem-fasakh-nya dalam jangka waktu tertentu sesuai dengan kesepakatan dalam akad.11

b. Khiyār ta'yīn

Khiyār ta'yin adalah hak pilih bagi pembeli dalam menentukan barang yang menjadi objek kontrak pada waktu tertentu sesuai dengan kesepakatan. Khiyār ta'yin berlaku apabila objek kontrak hanya satu dari sekian banyak barang yang berbeda kualitas dan harganya satu pihak pembeli misalnya diberi hak menentukan mana yang akan dipilihnya. ${ }^{12}$

2. Melekat pada akad (khiyār hukmiyyah). ${ }^{13}$

a. Khiyār ru'yah

Khiyār ru'yah adalah hak yang dimiliki pihak akad yang melakukan transaksi pembelian barang, tetapi belum melihat barang yang dibelinya untuk membeli atau membatalkan (tidak jadi membeli) saat melihat barang. ${ }^{14}$

\footnotetext{
8 Oni Sahroni and M Hasanudin. (2016). Fikih Muamalah Dinamika Teori Akad dan Implementasinya dalam Ekonomi Islam. Jakarta: Rajawali Press, h. 111.

9 Sahroni and Hasanudin, h. 111.

10 Amirudin. (2005). Penjelasan Kitab Shahih Bukhari, Juz 12, Hadits No. 2111. Jakarta: Pustaka Azzam, h. 127.

11 Oni Sahroni dan M. Hasanuddin, Op. Cit., h. 121.

$12 \mathrm{Ibid}, \mathrm{h} .125$.

13 Ibid, h. 111.

14 Ibid.
} 


\section{b. Khiyār'aib}

Khiyār 'aib adalah hak untuk membatalkan atau melangsungkan kontrak bagi kedua belah pihak yang berakad, apabila terdapat suatu cacat pada objek kontrak, dan cacat itu tidak diketahui pemiliknya ketika kontrak berlangsung. ${ }^{15}$

Selain dari pembagian macam-macam khiyār di atas terdapat macam khiyār yang lain, yaitu khiyār majlis. Khiyār majlis adalah hak memilih bagi para pihak yang melakukan akad untuk meneruskan atau membatalkan akad selama para pihak masih dalam tempat akad. 16

\section{B. HASIL PENELITIAN}

Ulin Ol Shop merupakan salah satu pelaku usaha dagang dengan memanfaatkan media sosial yang dirintis oleh Ulin Ni'matil Khasanah dari Keragilan, Gebang, Purworejo. Ulin ol shop mulai merintis usahanya pada awal tahun 2018. Pada awal merintis usaha ol shop ini Ulin terinpirasi dari banyaknya postingan-postingan di media sosial facebook (FB) yang menawarkan barang-barang untuk dijual dengan harga yang lebih murah dari harga barang-barang ditoko sekitar Purworejo, dari postinganpostingan Ulin Ol Shop tersebut Ulin menilai ada peluang untuk usaha. ${ }^{17}$

Pada awal memulai usahanya Ulin ol shop mengambil produk dari Semarang untuk dijual dan hanya menjual baju-baju wanita dan berbagai macam model hijab karena Ulin Ol Shop menilai bahwa peluang terbesar untuk menjadi konsumen adala h wanita yang mudah tertarik dengan promosi-promosi barang dengan harga yang murah. Seiring berjalannya waktu usaha semakin berkembang sehingga Ulin Ol Shop menambah produk yang dia jual, Ulin ol shop menjual peralatan dapur, kosmetik dan bara ng-barang laki-laki seperti tas, jam tangan dan pakaian-pakaian laki-laki dan hingga sekarang Ulin Ol Shop banyak menjual pernak pernik penghias di rumah seperti lampu-lampu hingga cover tembok. Hasil dari penjualan pun semakin bertambah karena barang-barang baru yang ditawarkan Ulin ol shop mendapat respon baik dari para konsumennya. ${ }^{18}$

Tatacara pelaksanaan jual beli secara online di Ulin OL Shop:

\section{Pemesanan}

Pada umumnya konsumen melihat postingan Ulin Ol Shop yang menawarkan produknya, dari postingan itu konsumen bisa memberikan komentar atau langsung mengirim pesan chat Whatsapp kepada Ulin OlShop. Beberapa konsumen yang telah berlangganan langsung mengirim pesan chat whatsapp (WA) kepada Ulin untuk menanyakan produk yang ingin konsumen beli, apabila produk yang konsumen inginkan masih tersedia maka produk tersebut akan di keep dan memberikan konfirmasi barang kepada konsumen. Namun apabila produk yang diinginkan konsumen tidak tersedia maka Ulin akan memberi tahu konsumen bahwa produk

\footnotetext{
$15 \mathrm{Ibid}, \mathrm{h} .118$.

16 Ibid, h. 127.

17 Wawancara dengan Ulin Ni'matil Khasanah pemilik usaha Ulin Ol Shop Purworejo pada tanggal 26 Februari 2020 pukul 14. 30 WIB.

18 Ibid.
} 
sedang kosong, apabila konsumen bersedia menunggu maka Ulin akan memesankan produk yang diinginkan konsumen ke produsen dari Ulin OlShop.

2. Pengiriman produk

Dalam mengirim produk kepada konsumen, Ulin Ol Shop menggunakan dua cara yaitu:

1) $C O D$ (Cash on Delivery) khusus untuk daerah Purworejo dengan pembayaran secara langsung dengan pengiriman produk di tempat yang telah disetujui untuk bertemu antara konsumen dan Ulin.

2) Jasa pengiriman paket untuk konsumen luar daerah Purworejo dan uang akan diserahkan melalui via tranfer ke rekening Ulin Ol Shop. ${ }^{19}$

Untuk membuat konsumen tertarik terhadap produk yang tawarkan oleh Ulin O1 Shop maka Ulin Ol Shop memposting foto-foto produk yang bagus dan terlihat menarik dengan model yang profesional di media sosial. Biasanya konsumen wanita akan lebih mudah tertarik melihat model yang memiliki tubuh proposional dengan mengenakan produk yang dijual, dengan model yang cantik dan tampan serta tubuh yang proposional akan memberikan kesan yang lebih menarik terhadap produk yang dijual. Cara ini merupakan salah satu strategi pemasaran Ulin Ol Shop untuk memasarkan produk-produk yang dijualnya, namun dalam memposting beberapa produk yang dijualnya Ulin Ol Shop tidak memberikan keterangan yang rinci mengenai produknya dan hanya menyertakan nomor WA yang dapat dihubungi.

Karena hal ini banyak konsumen yang menilai produk dari gambarnya saja tan pa keterangan rinci bagaimana mutu, kualitas dan keadaan produk yang sebenarnya. Akibatnya pada saat produk yang dibeli sampai di tangan konsumen, konsumen kecewa dengan keadaan produk yang sebenarnya tidak sesuai dengan keinginan konsumen. Hal ini membuat konsumen melakukan komplain kepada Ulin Ol Shop, bagi konsumen yang kecewa dan merasa dirugikan menginginkan produk yang telah dibeli untuk dikembalikan kepada Ulin O1Shop dan uangnya kembali. ${ }^{20}$ Namun Ulin Ol Shop tidak mau produk yang telah dipesan dikembalikan lagi karena dianggap konsumen telah setuju membeli produk tersebut. ${ }^{21}$

Untuk menjaga kepercayaan konsumen agar tetap berlangganan kepada Ulin O1 Shop, Ulin Ol Shop mencoba menjelaskan dengan memastikan bahwa barang yang dipesan itu benar dengan melakukan cek ulang terhadap transaksi yang telah disepakati. Sebagai rasa tanggung jawab Ulin karena mengecewakan konsumennya, Ulin Ol Shop biasanya akan memberikan potongan harga dari produk yang mengecewakan itu. ${ }^{22}$

Dari kasus yang pernah terjadi di Ulin Ol Shop dimana konsumen merasa tidak puas dengan produk yang dibelinya dari Ulin Ol Shop karena warnanya yang tidak

${ }^{19} \mathrm{Ibid}$.

20 Wawancara dengan Anis konsumen Ulin Ol Shop Purworejo pada tanggal 27 Februari 2020 pukul 15.15 WIB.

21 Wawancara dengan Ulin Ni'matil Khasanah pemilik usaha Ulin Ol Shop Purworejo pada tanggal 26 Februari 2020 pukul 14.30 WIB.

22 Ibid. 
sesuai dengan harapan konsumen pada saat melihat postingan Ulin Ol Shop dan ingin membatalkan pemesanannya, hal ini terjadi karena Ulin Ol Shop tidak memberikan informasi dengan jelas mengenai produk yang dijualnya melalui media sosial yang ia gunakan untuk mempromosikan produk yang dijualnya. Berdasarkan UUPK hal ini telah melanggar pasal 7 point $b$ tentang kewajiban pelaku usaha, yaitu memberikan informasi yang jelas jujur mengenai produk yang dijualnya, namun pemberian potongan harga dari Ulin OlShop kepada konsumen yang kecewa dengan produknya merupakan sikap tanggung jawab pelaku usaha berupa ganti rugi.

Ketika konsumen ingin membatalkan pesanan dan Ulin OlShop menolaknya itu merupakan hak Ulin Ol Shop sebagai pelaku usaha. Pada awalnya konsumen telah menghubungi kontak WA dari Ulin Ol Shop untuk menanyakan produk dari Ulin Ol Shop dalam obrolan pesan WA antara konsumen denga Ulin Ol Shop menanyakan beberapa hal mengenai produk yang konsumen minati dari Ulin Ol Shop dan akhinya konsumen sepakat untuk memesan produk tersebut dari Ulin Ol Shop. Dari obrolan pesan WA tersebut telah terjadi kesepakatan antara konsumen dan Ulin Ol Shop sehingga ketika konsumen ingin membatalkan pesanan tersebut itu telah melanggar hak pelaku usaha untuk mendapat pembayaran dari kesepakatan yang telah dilakukan.

Adanya khiyār dalam transaksi jual beli bertujuan untuk kemaslahatan bersama antara pelaku usaha dan konsumen, memastikan kedua belah pihak tidak akan merasa dirugikan dan menyesal nantinya setelah transaksi dilakukan. Khiyār diterapkan pada semua jenis transaksi jual beli termasuk jual beli online. Meskipun dalam transaksi jual beli online antara pelaku usaha dan konsumen tidak bertemu langsung, namun hak khiyār dapat diterapkan dengan menerapkan jenis khiyār yang sesuai dengan jual beli online yang dijalankan seperti khiyār ru'yah yang memberikan hak memilih bagi pihak yang melakukan akad jual beli, namun belum melihat barangnya sehingga dapat melanjutkan atau membatalkan akad ketika melihat barangnya. Seperti yang dijelaskan oleh Imam Syafi'i:

Imam Syafi'i r.a berpendapat: syarat yang membolehkan di setiap jual beli baik dibayar utang maupun kontan yang di sebut jual beli. Sesungguhnya jual beli itu tidak ada yang tetap pada penjual dan pembeli hingga mereka berdua berkumpul untuk saling transaksi jual beli dengan saling ridha. Tidak boleh keduanya melakukan akad jual beli dengan perintah atau larangan (dengan paksaan). Dan tidak diperbolehkan melakukan akad jual beli atas sesuatu yang di larang dalam jual beli. Ketika semua syarat tersebut telah terpenuhi maka jual beli tersebut telah sah. Dan tidak boleh mengembalikan barang yang telah dibeli kecuali dengan khiyār. Khiyār 'aib ketika ditemukan cacat pada barang, khiyār syarat disebutkan syaratnya, khiyār ru'yah. ${ }^{23}$

Dari pendapat yang disampaikan Imam Syafi'i menyatakan bahwa di setiap jual beli memiliki hak khiyār, sehingga konsumen dapat membatalkan atau meneruskan jual beli. Sebagaimana juga pendapat ahli fikih mengenai khiyār, yang berarti hak yang dimiliki salah satu atau seluruh pihak akad untuk melanjutkan akad atau membatalkannya, baik karena alasan syar'i atau karena kesepakatan pihak-pihak akad

${ }^{23}$ Muhammad bin Idrīs As-Syafi'i. (2001). Al-Umm, Juz 4. Pakis: Darul Wafa, h. 122. 
Ulin Ol Shop memberikan hak memilih produk dalam transaksi jual belinya dengan cara setiap konsumen berhak memilih produk mana yang akan ia beli dan menanyakan informasi mengenai produk yang diminatinya kepada Ulin Ol Shop melalui media chatting WA. Setelah konsumen menentukan pilihannya dan melakukan kesepakatan dengan Ulin Ol Shop maka Ulin Ol Shop menganggap konsumen telah melakukan kesepakatan transaksi jual beli sehingga konsumen tidak boleh mengembalikan produk yang telah dibelinya. Ketika ada ketidak puasan dari konsumen Ulin Ol Shop akan memberikan ganti rugi berupa potongan harga dari produk tersebut dan produk tetap harus dibeli oleh konsumen.

Ulin Ol Shop mengaku tidak begitu memahami mendalam mengenai teori khiyār, sehingga ia menganggap hak memilih barang yang telah ia berikan kepada konsumen sebelum konsumen memutuskan untuk membuat kesepakatan dengan Ulin O1 Shop mengenai produk mana yang akan konsumen beli itu adalah hak khiyār yang telah ia berikan kepada konsumen. Bentuk tanggung jawab Ulin Ol Shop sebagai pelaku usaha ketika ada konsumennya yang merasa kecewa terhadap produk yang dibelinya adalah dengan cara Ulin Ol Shop memberikan potongan harga dari produk yang mengecewakan itu. Dari cara Ulin OlShop memberikan hak memilih bagi konsumenn ya seperti di a tas tidak sesuai dengan teori khiyār dalam Hukum Islam, dalam Hukum Islam hak khiyār yang dimaksud adalah hak memilih untuk meneruskan atau membatalkan akad jual beli, bukan sekedar hak bagi konsumen untuk memilih barang mana yang akan dia beli.

1. Analisis Perilaku Ulin OlShop

Pelaksanaan Pasal 7 UU Nomor 8 Tahun 1999 tentang Perlindungan Konsumen (UUPK) di Ulin Ol Shop belum sepenuhnya dijalankan karena pada setiap postingan media sosial Ulin Ol Shop gambar produk yang dijual Ulin Ol Shop tidak disertakan informasi yang lengkap mengenai produk, hal ini tidak sesuai dengan Pasal 7 hur uf b yang mengharuskan pelaku usaha memberikan informasi yang jelas dan jujur mengenai produk yang dijualnya. Ulin Ol Shop selalu memberikan hak bagi konsumennya untuk memilih produk mana yang akan dibelinya untuk semua konsumen dan memberikan ganti rugi atas produk yang tidak memuaskan bagi konsumen dengan cara memberikan potongan harga.

Menurut hukum Islam setiap jual beli memiliki hak khiyār yaitu memilih meneruskan atau membatalkan transaksi jual beli. Berdasarkan teori khiyār Ulin Ol Shop tidak menerapkan sepenuhnya karena setiap produk yang tidak memuaskan bagi konsumen tidak boleh dikembalikan, Ulin Ol Shop hanya memberikan potongan harga. Meskipun berdasarkan Pasal 7 UUPK tindakan Ulin Ol Shop ini dibenarkan karena Ulin Ol Shop telah memberikan ganti rugi berupa potongan harga, namun menurut teori khiyār hal ini tidak sesuai karena pengertian khiyār adalah memilih untuk meneruskan atau membatalkan akad sedangkan yang Ulin OlShop terapkan ini hanya sekedar memilih barang melalui media sosial saja sehingga masih ada kemungkinan konsumen merasa kecewa terhadap produk yang dibelinya setelah konsumen menerima dan melihat langsung produk tersebut. 
Mayoritas konsumen Ulin Ol Shop adalah perempuan dari segala kalangan baik remaja maupun orang tua atau kaum ibu-ibu. Konsumen perempuan lebih mudah tertarik dengan barang-barang yang terlihat menarik, seringkali perempuan membeli barang bukan karena kebutuhan namun hanya karena keinginan. Perempuan lebih mudah tertarik pada suatu barang tanpa mempertimbangkan manfaat dari barang yang dibeli, hal ini menjadi peluang besar bagi pelaku usaha Ol Shop salah satunya Ulin Ol Shop. Ulin Ol Shop seringkali memposting barang-barang yang dijualnya melalui akun media sosialnya, gambar-gambar barang yang dipostingnya dibuat semenarik mungkin agar menarik minat konsumen terlebih para perempuan karena sebagian besar barang yang dijual Ulin Ol Shop adalah barang-barang untuk perempuan dan perabotan rumah tangga. Dari postingan barang yang dijual Ulin Ol Shop di akun media sosial membuat banyak orang yang melihat barang-barang yang dijual Ulin OlShop, Ulin Ol Shop menjual barang-barang dagangannya dengan harga yang lebih murah dari harga pasaran sekitar Purworejo, sehingga lebih menarik konsumen untuk membeli kepada Ulin Ol Shop.

2. Analisis Perilaku Konsumen Ulin Ol Shop

Ketika akan membeli barang sebagai konsumen yang baik langkah pertama yang perlu dilakukan adalah menilai kebutuhan dan manfaat dari barang yang akan dibeli, kemudian memilih baranga mana yang sesuai dengan kebutuhan dan kemampuan dari konsumen. Dalam Pasal 4 UUPK poin ke 3 di jelaskan bahwa salah satu hak konsumen adalah sebagai berikut: "Hak atas informasi yang benar, jelas dan jujur mengenai kondisi dan jaminan barang dan/atau jasa" 24

Dari pasal di atas telah dijelaskan bahwa dalam memilih barang konsumen da pat mencari informasi dari barang yang akan dibeli, sebagai konsumen Ol Shop seharusnya lebih teliti dalam memilih barang yang akan dibelinya, karena barang yang akan dibeli tidak bisa dipilih secara langsung. Karena dalam memposting barang-barang yang dijualnya Ulin OlShop tidak selalu menyertakan informasi yang detail maka sebagai konsumen harusnya lebih aktif untuk bertanya mengenai informasi barang yang diminati kepada Ulin OlShop karena Ulin OlShop menerima segala pertanyaan menganai barang yang dijualnya jika konsumen bertanya. Beberapa faktor penyebab konsumen kecewa dengan barang yang dibelinya adalah karena konsumen kurang teliti dalam mencari informasi mengenai barang yang akan dibelinya.

Ketika telah ada transaksi antara pelaku usaha (Ulin Ol Shop) dan konsumen dalam obrolan chat dan mencapai kesepakatan, maka konsumen dianggap telah membeli barang yang telah disepakati, sehingga konsumen wajib melaksanakan kewajiban konsumen yang dijelaskan dalam Pasal 5 UUPK poin c, yaitu: “Membayar sesuai dengan nilai tukar yang disepakati" 25

Ketika barang sampai kepada konsumen dan tenyata barang tersebut tidak sesuai dengan harapan konsumen, barang tersebut sudah tidak dapat dikembalikan kepada

${ }^{24}$ Undang-Undang Republik Indonesia Nomor 8 Tahun 1999 tentang Perlindungan Konsumen.

25 Ibid. 
Ulin Ol Shop kembali, sebagai ganti rugi atas rasa kecewa konsumen Ulin Ol Shop memberikan ganti rugi berupa potongan harga.

Dalam transaksi jual beli haruslah menuju kemaslahatan bersama antara konsumen dan pelaku usaha dan tidak merugikan pihak mana pun, ketika seorang konsumen menginginkan untuk membatalkan barang yang dibelinya dan uangnya kembali setelah kesepakatan, maka hal ini akan merugikan pelaku usaha yang telah berusaha memenuhi keinginan konsumen. Jika konsumen marasa kecewa karena barang yang dibelinya tidak sesuai dengan harapan dan mera sa dirugikan, Ulin O1 Shop memberikan ganti rugi berupa potongan harga.

\section{PENUTUP}

Ditinjau dari Pasal 7 UU Nomor 8 Tahun 1999 tentang Perlindungan Konsumen Ulin Ol Shop telah menyalahi Pasal 7 Huruf $b$ mengenai pemberian informasi kepada konsumen. Ulin Ol Shop tidak menerapkan hak khiyar sesuai hukum Islam, karena ia tidak mau menerima pengembalian barang setelah kesepakatan dalam obrolan via chatting WA. Faktor penyebab kasus pada konsumen Ulin OlShop adalah karena Ulin Ol Shop yang tidak memberikan informasi yang lengkap pada gambar barang yang dipostingnya, dan konsumen yang kurang teliti dalam memilih untuk membeli barang. Konsumen memiliki kewajiban ketika telah terjadi kesepakatan sehingga konsumen tidak bisa membatalkan transaksi secara sepihak.

Bagi Ulin Ol Shop, penulis menyarankan supaya setiap postingan produk yang ditawarkan melalui media sosial selalu disertai keterangan lengkap mengenai produk tersebut, sehingga konsumen bisa langsung mengetahui produk dengan jelas. Bagi para konsumen Ulin ol shop dan semua konsumen jual beli online diharapkan lebih teliti menanyakan informasi yang jelas mengenai produk yang akan dibelinya, supaya tidak akan kecewa dengan produk setelah produk sampai ke tangan konsumen.

\section{DAFTAR PUSTAKA}

Al-Ghozi, Abi Abdillah Muhammad al-Qosim. (2017). Fathul Qorib Mujib. alih bahasa oleh Ibnu Abi Zain. Kediri: Zam-Zam Sumber Mata Air Ilmu.

Ali, Muhammad. (1993). Penelitian Pendidikan; Prosedur dan Strategi. Bandung: Angkasa.

Amirudin. (2005). Penjelasan Kitab Shahih Bukhari. Juz 12, Hadits No. 2111. Jakarta Pustaka Azzam.

Arikunto, Suharsimi. (2000). Prosedur Penelitian Suatu Pendekatan Praktikedisi V. Bandung: Rineka Cipta.

Bukhari, Abu Abdillah, Muhammad bin Ismail alju'fi. Muhammad Zuhair bin Nasir anNasir (Ed). 1422 H. Shohihul Bukhari. Cet I. Beirut: Darun Thauqin Najat.

Harun. (2017). Fiqh Muamalah. Surakarta: Muhammadiyah University Press.

Kristiyanti, Celina TriSiwi. (2009) Hukum Perlindungan Konsumen. Jakarta: Sinar Grafika. Muhajir. (2021). “Analisis Hukum Islam Terhadap Pembulatan Tarif Layanan Jasa Transportasi KOPADA TAKSI Di Purworejo" . Ulumuddin: Jurnal Ilmu-ilmu Keislaman. Volume 11. Nomor 2. 
Sahroni, Ono dan M. Hasaudin. (2018). Fikih Muamalah Dinamika Teori Akad dan Implementasinya dalam Ekonomi Syariah. Depok: PT Raja Grafindo Persada.

Sidabalok, Janus. (2010). Hukum Perlindungan Konsumen di Indonesia. Bandung: PT Citra Aditya Bakti.

Undang-Undang Republik Indonesia Nomor 8 Tahun 1999 tentang Perlindungan Konsumen.

Wawancara dengan Anis konsumen Ulin Ol Shop Purworejo pada tanggal 27 Februari 2020 pukul 15. 15 WIB.

Wawancara dengan Lili, Riska dan Evi konsumen Ulin Ol Shop Purworejo pada tanggal 27 Februari 2020 pukul 15.15 WIB.

Wawancara dengan Ulin Ni'matil Khasanah pemilik usaha jual beli online Ulin Ol Shop Purworejo pada tanggal 25 Oktober 2019 pukul 22. 30 WIB. 